\title{
The influence of salt stress on the morpho physiological and biochemical parameters of durum wheat varieties (Triticum durum Desf.)
}

\author{
Nadia Chiahi ${ }^{1}$ and Louhichi Brinis ${ }^{2}$ \\ ${ }^{1}$ Laboratory for Terrestrial and Aquatic Ecosystems, Mohamed-Cherif Messaadia University, Souk Ahras, ${ }^{2}$ Plant Genetic \\ Improvement Laboratory, Department of Biology, Badji Mokhtar Annaba University, Algeria
}

\section{Abstract}

Wheat is an important cereal in terms of human consumption in many countries of the world. It is grown mainly in arid and semi-arid Mediterranean countries. In these areas, salinity of soils and irrigation water is one of the limiting factors in plant productivity and agricultural yield.

The present work consisted in evaluating the morpho-physiological and biochemical behavior of two durum wheat varieties V1 (Gta dur), V2 (Vitron) subjected to increasing concentrations of $\mathrm{NaCl}$ during the germination phase and the growth phase in the laboratory.

The results obtained showed several revelations in terms of morphological imbalance (leaf area, germination percentage, root length, physiological variation, decrease or increase of assimilating pigments, Relative Water Content (RWC), etc), and biochemical bioaccumulation (proline, soluble sugars, proteins and elevation of activity of CAT antioxidant enzymes).

At the level of treatments, the development of the seedlings of two varieties was better on soil salty and sprinkled with water than in the presence of saline concentrations.

A certain tolerance of the two genotypes was particularly marked in the Vitron variety against salt stress.

Correspondence: Nadia Chiahi, Laboratory for Terrestrial and Aquatic Ecosystems - Mohamed-Cherif Messaadia University, Souk Ahras, Algeria.

E-mail: nchiahidz@gmail.com

Key words: salt stress, durum wheat, germination, growth, morphological, physiological and biochemical parameters, antioxidant enzymes.

Conflict of Interest: The Authors declare no potential conflict of interests.

Received for publication: 3 December 2018.

Accepted for publication: 6 February 2020.

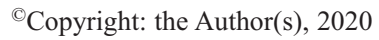

Licensee PAGEPress, Italy

Journal of Biological Research 2020; 93:7966

doi:10.4081/jbr.2020.7966

This article is distributed under the terms of the Creative Commons Attribution Noncommercial License (by-nc 4.0) which permits any noncommercial use, distribution, and reproduction in any medium, provided the original author(s) and source are credited.

\section{Introduction}

Cereals are an important part of human and animal food resources. ${ }^{1}$ Among cereals, durum wheat (Triticum durum Desf.) is one of the oldest species and constitutes a large part of the diet of humanity, hence its economic importance. It accounts for a great part of the nutrition of the world's population, which is provided by grain feeds, $95 \%$ of which are produced by major cereal crops. $^{2}$ Algeria, before the 1830 , exports its wheat in the whole world. Currently Algeria imports its wheat and is dependent on the international market. With its position as a major wheat importer, Algeria buys more than $5 \%$ of the world's cereal production annually; this situation is likely to last for several years due to the of sufficient yields and ever-increasing consumption needs in the face of a strong demographic evolution. Much of the grain is concentrated in the interior of the country in arid and semi-arid areas, characterized by cold winters, irregular rainfall patterns, frequent spring frosts, and hot, dry winds at the end of the rainy season culture. All these constraints affect cereal production, which is characterized by a very variable annual national average. ${ }^{2}$

Arid and semi-arid lands make up one-third of the world's surface. In these areas, salinity of soils and irrigation water are limiting factors in plant productivity and agricultural yield. According to the most recent estimates, they are already affecting at least 400 million hectares and are seriously threatening an equivalent area. ${ }^{3}$ These ecosystems are characterized by low and highly irregular rainfall, associated with significant evaporation favoring the accumulation of salts in the soil. ${ }^{4}$ Algeria is among the affected countries; almost 3.2 million hectares of surface are saline. ${ }^{5}$ Indeed, depending on the degree of salinity in the medium, glycophytes in particular are exposed to changes in their morpho-physiological, biochemical and mineral features. ${ }^{6}$ Thus; plants react to salinity variations in the biotope triggering resistance mechanisms. Osmotic adjustment is an effective mechanism of drought resistance in a strategy of low water potential of the plant. It ensures the maintenance of turgescence by accumulation of solutes. ${ }^{7}$

This phenomenon appears today as a major mechanism of adaptation to ionic and osmotic stress, which is expressed by the ability of a plant to accumulate active ions, such as $\mathrm{Na}^{+}$and $\mathrm{Cl}^{-8,9}$ or organic compounds such as soluble sugars ${ }^{10}$ and certain amino acids such as proline. ${ }^{11}$ Saline stress generates the accumulation of toxic compounds such as Reactive Oxygen Species (ROS) in cellular tissues. The ROS represent peroxides, superoxide and hydroxyl radicals. ${ }^{12,13}$ These toxic molecules damage cell membranes, enzymes and mitochondrial and chloroplast DNA, disrupting plant growth and survival. ${ }^{14,15}$ Intense saline stress results in reduced production of auxin, gibberellins and cytokinines in cellular tissue and increases Abscisic Acid (ABA) concentration. ${ }^{16}$ 
The enzymes responsible for detoxification, called antioxidants, include Superoxide Dismutase (SOD), Catalase (CAT), and enzymes of the ascorbate-glutathione cycle. ${ }^{17}$

Our work consists in studying the effect of salt stress on two varieties of durum wheat grown in Algeria, V1 (Gta dur) and V2 (Vitron), in order to highlight the morphological, physiological and biochemical responses.

\section{Materials and Methods.}

At the 4 to 5 leaf stage, three samples were selected for each variety and treatment (control and stressed). Plants were removed completely (i.e., with their roots) carefully, rinsed with waste and wiped thoroughly using blotting paper. These plants were weighed and the fresh weight of the plant was obtained, then the plants were cut into two parts: aerial and root, and both parts were weighed. Samples were then set to dry in the oven at $85^{\circ} \mathrm{C}$ for 24 hours, and then weighed, obtaining the dry weight. The biomass was assessed by the following formula:

$$
\text { (DM) Dry Matter }(\%)=/ \mathrm{DW} / \mathrm{FP}) \times 100
$$

DM: dry matter; DW: dry weight of the plant.; FP: fresh plant weight

The test was carried out at the plant biology laboratory at the Mohamed Cherif Messadia Souk Ahras University, Algeria. The study focused on two varieties, GTA Dur and Vitron Durum (Triticum durum Desf.). The genotypes used are listed according to the TIFC (Technical Institute for Field Crops) official catalog.

Our work consisted of two experiments: the first was dedicated to the trial of two durum wheat varieties (GTA dur and Vitron) in the soil, and the second was devoted to the germination test in Petri dishes. These two tests were carried out in the Biology Laboratory at the University of Mohamed Cherif Messaadia (Souk Ahras, Algeria).

The chosen seeds were healthy and selected according to size, shape and color.

Seven seeds each were placed in plastic pots (30 pots) of length $34.5 \mathrm{~cm}$ and width $17.5 \mathrm{~cm}$, and sown in summer to a depth of $2 \mathrm{~cm}$ for both varieties.

Our device was divided into two random blocks, each block containing 5 treatments; each treatment was repeated 3 times (Figure 1).

In the laboratory, we tested the tolerance to salinity of $T$. durum at the same saline solutions utilized in the first experiment. We counted 10 seeds which were placed in Petri dishes. Control boxes were soaked with $10 \mathrm{ml}$ of distilled water and the other boxes were soaked with $10 \mathrm{ml}$ of solutions at different concentrations of $\mathrm{NaCl}$.

Our device was divided into two blocks, each block contained three treatments and each treatment was repeated three times. The experiment was carried out under laboratory conditions; the number of sprouted seeds was recorded after 24 hours until the 8 th day.

Soil texture was determined by measuring the percentage of soil moisture ( $\mathrm{H} \%)$, and comparing it to a scale that determines the corresponding texture. ${ }^{18}$

To measure $\mathrm{pH}-\mathrm{KCl}$ (acidity of exchange), twenty $\mathrm{g}$ of soil were placed in a $100-\mathrm{ml}$ beaker; after addition of $50 \mathrm{ml}$ of $\mathrm{KCl}(0.1$ $\mathrm{N}$ ) and shaking with a glass tube or a stirrer; $\mathrm{pH}$ was measured by a $\mathrm{pH}$ meter.

We have rinsed the active part with distilled water. Then we immersed the electrode in the solution to be studied. After a while to wait for the device indication to stabilize

After using the electrode, we rinsed with distilled water and replaced in the container containing $\mathrm{KCl}$; the saline water was classified according to the USSL Salinity Laboratory. 19

Leaf Surface (LS) was determined by a traditional method which consists on the one hand to reproduce the leaf blade of wheat on paper which is then weighed, and on the other hand to cut and weigh a square of $1 \mathrm{~cm}$ on the same paper side, allowing to deduce the surface. ${ }^{20}$

From the 30 pots, one pot was taken and irrigated with $500 \mathrm{ml}$ (Q1) water. After 15 minutes water in excess released from the soil was measured (Q2). We then deduce the capacity of the field (C.C) by the following formula:

$$
\text { C.C }=\text { Q1-Q2 }
$$

Where Q1 is the initial amount of irrigation water; Q2 is the excessive amount of water; C.C is the capacity in the field (the amount of water retained by the soil).

The Relative Water Content (RWC) was measured according to USSL Salinity Laboratory. ${ }^{19}$ The determination of the Water Loss Rate (WLR) was evaluated using the method of Maillard. ${ }^{21}$

To determine biomass (MS \%), at the 4-5 leaf stage, three samples were chosen for each variable and for each treatment (control and stressed).

The photoreceptor pigments were determined using the extraction of chlorophyll from the leaf tissue which was carried out according to the method of Maillard ${ }^{21}$ and Proline was determined according to Barrs. ${ }^{22}$ Soluble sugars were determined

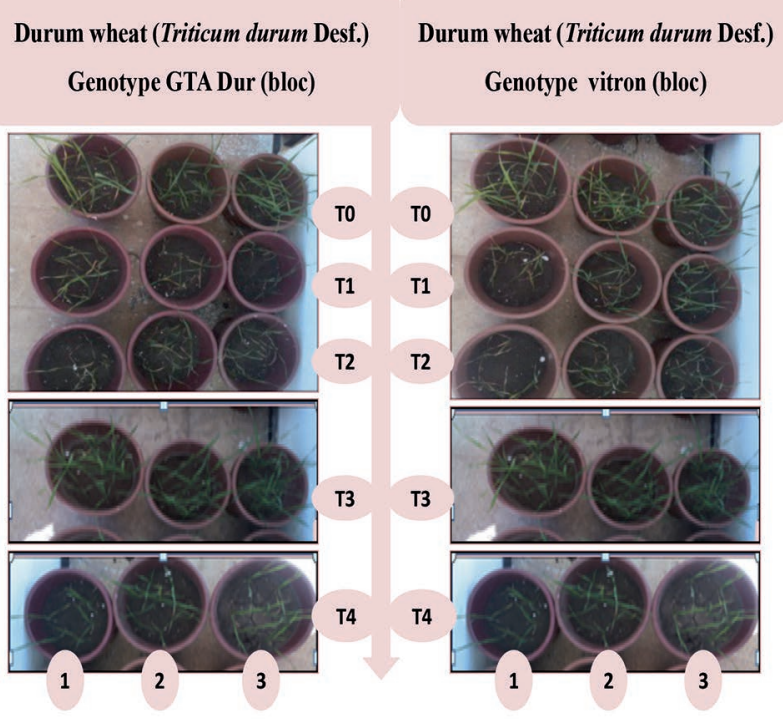

Figure 1. Experimental device scheme of the test. The experiment was carried out under ambient conditions: Control, irrigation with $0 \mathrm{~g} / 1 \mathrm{NaCl}$ (T0); Treatment 1, irrigation with Saline Solution containing $6 \mathrm{~g} / 1 \mathrm{NaCl}$ (T1); Treatment 2, irrigation with Saline Solution containing $9 \mathrm{~g} / 1 \mathrm{NaCl}$ (T2); Treatment 3 , sowing in pots on salty soil taken from the ruins of Khemissa (Souk Ahras, Algeria) and irrigated with drinking water (T3); Treatment 4, irrigation with salty spring water from Khemissa Souk Ahras (Algeria); Treatments 1, 2, 3, and 4 were carried out with soil taken from the agricultural field of pilot farm "Yousfi Tayeb Tifech" Souk Ahras, Algeria. 
according to McKinney-Arnon, ${ }^{23}$ which uses the enthrone in a sulfuric medium.

The extraction of soluble sugars was done cold, by putting for 24 hours $100 \mathrm{mg}$ of fresh plant material (taken in the middle third of the leaf) in test tubes to which $3 \mathrm{ml}$ of alcohol ( $80 \%$ ethanol) were added. The solution then was passed to the rotary evaporator (or water bath at $70^{\circ} \mathrm{C}$ for 30 minutes). Once the alcohol was evaporated, $20 \mathrm{ml}$ of distilled water were added throughout the extract.

The anthrone reagent was prepared four hours in advance, by mixing 0.2 gr of anthrone in $100 \mathrm{ml}$ of sulfuric acid, and stored in a dark bottle.

The biological samples and standard series of the calibration range were assayed in parallel. Total proteins were quantified by enzymatic extraction according to McKinney-Arnon. ${ }^{23}$ Catalase activity (CAT) was performed according to Monneveux and Nemmar. ${ }^{24}$

The maximum length of the roots is the length of the longest root, measured with a millimeter paper.

Determining final Germination rate $(\mathrm{G} \%)$ and number of root is the best way to identify the saline concentration corresponding to the physiological germination limit of durum wheat seeds. It is expressed by the ratio of sprouted seeds to the total number of seeds. The final percentage of Germination $(\mathrm{G} \%)$ was determined as:

$$
\mathrm{G} \%=100(\mathrm{XT} / \mathrm{N})
$$

Where XT is the total number of germinated seeds and $\mathrm{N}$ is the total number of seeds germinated. ${ }^{23}$

\section{Results}

Physico-chemical parameters of soil are reported in Table 1. Electrical conductivity (EC) is an important parameter to detect the salinity of a soil; the value recorded for the Tifech soil was $0.2 \mathrm{mS}$ $\mathrm{cm}^{-1}$. We found that the soil under study is in the range between 0 and $0.60 \mathrm{mS} \mathrm{cm}{ }^{-1}$ which indicates that the analyzed samples are non-saline. However, the value recorded for the Khemissa soil was $0.85 \mathrm{mS} \mathrm{cm}^{-1}$ depending on the salinity scale. ${ }^{25}$ The analyzed soil is not very saline.

The Electrical Conductivity (EC) of the irrigation water was $0.99 \mathrm{mS} \mathrm{cm}^{-1}$; itis in the range of 0.7 to $2 \mathrm{mS} \mathrm{cm}^{-1}$, which indicates that the analyzed water is slightly saline.

To differentiate between the two varieties, we compared the means relative to LS, RWC, RWL, MS\%, Chla, Chl b, and Chl (a $+\mathrm{b}$ ), carotenoids and some biochemical parameters (Proteins, Sugars, Proline and Catalase) of the two varieties under salt stress; we applied the parametric test of Student and the results are indicated in Table 2 .

The analysis in Table 2 shows that there are not significant differences $(p \geq 0.05)$ between the two varieties of wheat in the length and the number of roots, $\mathrm{G} \%$, and $\mathrm{MS} \%$. Significant differences ( $\mathrm{p}$ $\leq 0.05$ ) are reported in $\mathrm{LS}, \mathrm{RWC}, \mathrm{RWL}, \mathrm{Chl}$ a, Chl b, carotenoids, proline and soluble sugars. Highly significant differences $(\mathrm{p}<0.01)$ in $\mathrm{Chl}(\mathrm{a}+\mathrm{b})$, proteins, and catalase.

To differentiate the differences between treatments for each variety, we compared the morpho-physiological parameters LS, RWC, RWL, MS\%, Chl a, Chl b, Chl (a+b), carotenoids and biochemical parameters (proteins, sugars, proline and catalase) under salt stress. We applied the non-parametric Kruskal-Wallis test, to test the effect of different treatments within each variety. The results are shown in Table 3.
Table 1. Physico-chemical soil parameters (texture, pH, EC)

\begin{tabular}{lcccc} 
& Texture & pH water & $\begin{array}{c}\text { pH } \\
(\mathrm{KCl})\end{array}$ & $\begin{array}{r}\mathrm{ECmS} \\
\mathrm{cm}^{-1}\end{array}$ \\
Soil of Tifech (Algeria) & Sandy-silty & 7.8 & 7.15 & 0.2 \\
Soil of Khemissa (Algeria) & Silty sand & 8.18 & 7.70 & 0.85 \\
\hline
\end{tabular}

Table 2. Comparison of the median morpho-physiological and biochemical parameters analyzed in the two varieties.

\begin{tabular}{lccc} 
Settings & T obs & ddl & $P$ \\
LS & 0.69 & 28 & $0.03 \mathrm{~S}$ \\
RWC & 0.37 & 28 & $0.01 \mathrm{~S}$ \\
\hline WLR & 0.54 & 28 & $0.01 \mathrm{~S}$ \\
MS\% & 2.07 & 28 & 0.18 \\
\hline Chl a & 2.83 & 28 & NS \\
Chl b & 1.08 & 28 & $0.01 \mathrm{~S}$ \\
\hline Chl a+b & 1.46 & 28 & $0.01 \mathrm{~S}$ \\
Carotenoids & 2.46 & 28 & 0.009 \\
\hline Proline & 1.25 & 28 & HS \\
Sugars & 2.65 & 28 & $0.01 \mathrm{~S}$ \\
\hline Protein & 0.29 & 28 & $0.01 \mathrm{~S}$ \\
Catalase & 0.14 & 28 & $0.01 \mathrm{~S}$ \\
\hline Root length & 1.46 & 16 & 0.009 \\
G\% & 0.17 & 16 & HS \\
\hline Root number & 0.04 & 16 & 0.009 \\
& & & HS \\
& & & $1 \mathrm{NS}$ \\
& & & $1 \mathrm{NS}$ \\
\hline
\end{tabular}

LS: Leaf Surface; RWC: Relative water content; WLR: Water Loss Rate; MS\%: Dry matter content; G\%: final Germination rate; T obs: Observed Test; Ddl: Error degrees of liberty; S: Significant differences ( $\mathrm{p} \leq 0.05)$; HS: Highly Significant $(\mathrm{p}<0.01)$; NS: Not Significant differences $(\mathrm{p} \geq 0.05)$.

Table 3. Comparison of median morpho-physiological and biochemical parameters analyzed by treatment differences in the two varieties.

\begin{tabular}{lcc} 
Settings & $P(V 1)$ & $P(V 2)$ \\
LS & $0.02 \mathrm{~S}$ & $0.03 \mathrm{~S}$ \\
RWC & $0.02 \mathrm{~S}$ & $0.01 \mathrm{~S}$ \\
\hline WLR & $0.02 \mathrm{~S}$ & $0.01 \mathrm{~S}$ \\
MS\% & $0.04 \mathrm{~S}$ & $0.18 \mathrm{NS}$ \\
\hline Chl a & $0.009 \mathrm{HS}$ & $0.01 \mathrm{~S}$ \\
Chl b & $0.01 \mathrm{~S}$ & $0.01 \mathrm{~S}$ \\
\hline Chl a+b & $0.01 \mathrm{~S}$ & $0.009 \mathrm{HS}$ \\
Carotenoids & $0.01 \mathrm{~S}$ & $0.01 \mathrm{~S}$ \\
\hline Proline & $0.01 \mathrm{~S}$ & $0.01 \mathrm{~S}$ \\
Sugars & $0.01 \mathrm{~S}$ & $0.01 \mathrm{~S}$ \\
\hline Protein & $0.009 \mathrm{HS}$ & $0.009 \mathrm{HS}$ \\
Catalase & $0.01 \mathrm{~S}$ & $0.009 \mathrm{HS}$ \\
\hline Root length & $1 \mathrm{NS}$ & $1 \mathrm{NS}$ \\
G\% & $1 \mathrm{NS}$ & $1 \mathrm{NS}$ \\
\hline Root number & $1 \mathrm{NS}$ & $1 \mathrm{NS}$
\end{tabular}

LS: Leaf Surface; RWC: Relative water content; WLR: Water Loss Rate; MS\%: Dry matter content; G\%: final Germination rate; S: Significant differences ( $\mathrm{s} \leq 0.05)$; HS: Highly Significant $(\mathrm{p}<0.01)$; NS: Not Significant differences ( $\mathrm{p} \geq 0.05)$. 
Table 3 shows no significant differences ( $p \geq 0.05$ ) between the treatments for variety (V1) for root length, root number, and G\%. Significant differences $(\mathrm{p} \leq 0.05)$ were observed in LS, RWC, WRL, Chl b and Chl $(\mathrm{a}+\mathrm{b})$, carotenoids, proline, soluble sugar and catalase.

Highly significant differences $(\mathrm{p}<0.01)$ were observed in Chl $a$ and protein. There were non-significant differences $(p \geq 0.05)$ among treatment differences for the variety (V2) in the length and the number of roots, $\mathrm{G} \%$, MS $\%$. Significant differences $(p \leq 0.05)$ were reported for LS, RWC, RWL, Chl a, Chl b, carotenoids, proline and soluble sugars. Highly significant differences $(p<0.01)$ for $\mathrm{Chl}(\mathrm{a}+\mathrm{b})$, protein, catalase

As to the effect of salt stress on the two varieties of durum wheat, we obtained results as follows

The Leaf Surface measurements (LS) showed significant variations, which are illustrated in Figure 2. A significant decrease in the leaf size of the two varieties as a function of the levels of applied salt stress was recorded.

The RWC of both varieties is reported in Figure 3. The highest relative water levels were noted in the controls with a maximum value of $96.65 \%$. The increase in the level of applied stress (6 and $9 \mathrm{~g} / \mathrm{l})$ induced a decrease in water content in Gta dur and Vitron with $81.98 \%, 74.14 \%$, and 69.17 and $71.77 \%$, respectively.

The Water Loss Rate (WLR) showed a significant decrease in the two studied varieties as a function of the levels of the applied salt stress (Figure 4)

Regarding biomass (precent dry matter - MS\%), there was a decrease in both varieties compared to the control (Figure 5) at 6 $\mathrm{g} / 1 \mathrm{NaCl}$.

The result concerning $\mathrm{Chl}$ a content is reported in Figure 6, which shows that it responds negatively to salt stress; the control registers the highest content compared to $\mathrm{Chl}$ a level assayed for other salt concentrations.

Figure 7 shows that in the presence of salt, the content of Chl $\mathrm{b}$ decreased in both varieties.

The results show that, regardless of the variety (Gta dur and Vitron), the Chl $(\mathrm{a}+\mathrm{b})$ content is reduced compared to the control after irrigation with two saline solutions (Figure 8).

Under the effect of salt stress, the content of carotenoid pigments decreases in the V2 variety and increases in V1 (Figure 9).

Figure 10 shows that in the presence of salt stress there is an increase in the amount of proline in both varieties (V1 and V2) with high doses positively correlated with the degree of stress. The higher the dose, the higher the proline content

The results obtained (Figure 11) show that the increase of saline concentration induced a large accumulation of soluble sugars in the Gta dur variety with a maximum value of $171.28 \mu \mathrm{g} / \mathrm{g}$ of leaf mass for the dose $(6 \mathrm{~g} / 1)$. In addition, Vitron variety is characterized by significant accumulation with a maximum value of $153 \mu \mathrm{g} / \mathrm{g}$ leaf mass for the dose $9 \mathrm{~g} / \mathrm{l}$.

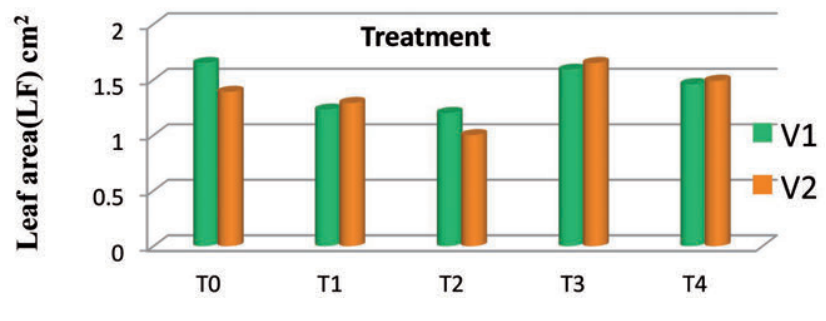

Figure 2. Variation of leaf area in both durum wheat varieties, depending on the intensity of salt stress.

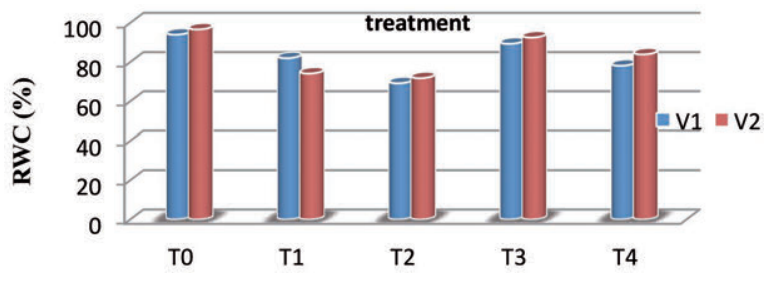

Figure 3. Variation in the Relative Water Content (RWC) of the two varieties of durum wheat exposed to different concentrations of $\mathrm{NaCl}$.

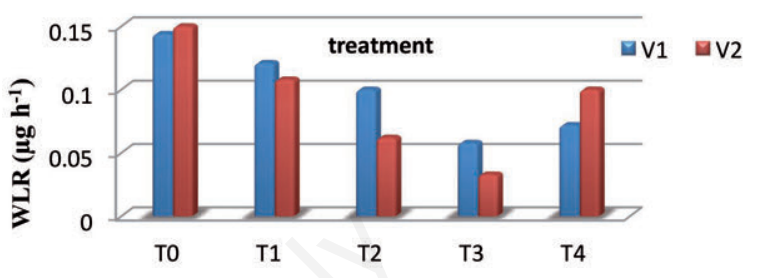

Figure 4. Variation in the Water Loss Rate (WLR) of the two varieties of durum wheat exposed to different concentrations of $\mathrm{NaCl}$.

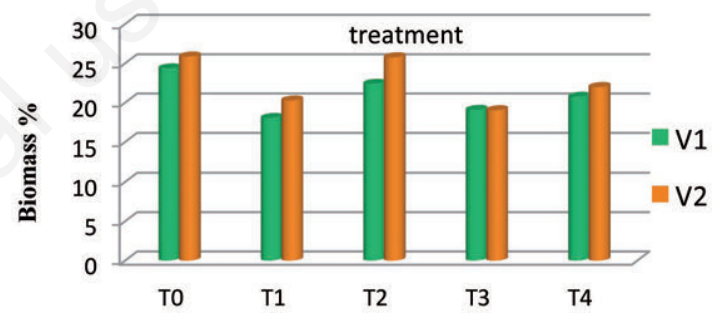

Figure 5. Variation of the biomass of the two varieties of durum wheat exposed to different concentrations of $\mathrm{NaCl}$.

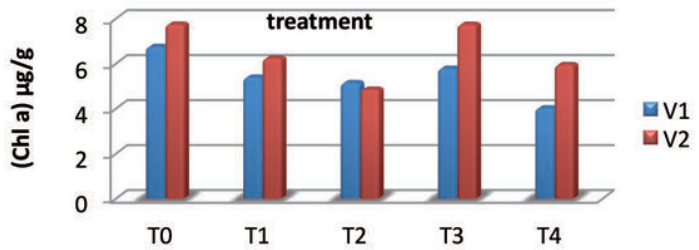

Figure 6. Variation in Chlorophyll a ( $\mathrm{Chl} \mathrm{a)} \mathrm{content} \mathrm{of} \mathrm{the} \mathrm{two}$ varieties of durum wheat exposed to different concentrations of $\mathrm{NaCl}$.

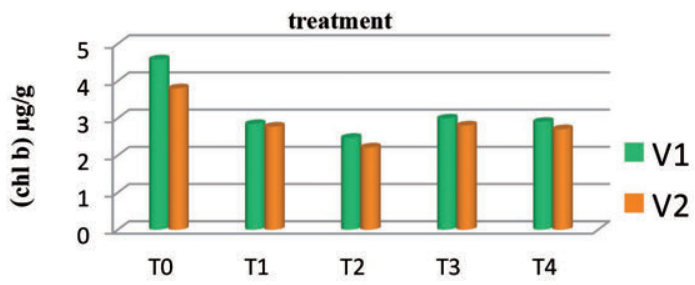

Figure 7. Variation in the Chlorophyll b $(\mathrm{Chl} \mathrm{b})$ content of the two varieties of durum wheat exposed to different concentrations of $\mathrm{NaCl}$. 
The protein content of both genotypes is reported in Figure 12. Salt treatment clearly favored protein synthesis in both varieties. The determination of the protein content showed that the severity of stress (high doses) favored a large accumulation of total proteins whose effect is proportional to the applied dose. The higher the dose, the higher the protein content.

The results of the catalase activity are shown in Figure 13. The treatment with saline solutions seems to cause a global increase in the activity of this enzyme compared with the controls.

The concentration of $\mathrm{NaCl}$ in the medium influences the root length of the two durum wheat genotypes studied (Figure 14). When exposed to 6 and $9 \mathrm{~g} / 1 \mathrm{NaCl}$, the two genotypes variety, Gta dur and Vitron, showed a decrease in root length: 6.81 and $5.06 \mathrm{~cm}$ when treated with $6 \mathrm{~g} / \mathrm{l}$, and 5.75 and $6.09 \mathrm{~cm}$ when treated with 9 $\mathrm{g} / \mathrm{l}$, respectively.

The germination rate of the two genotypes is reported in Figure 15. The results show that, whatever the variety (Gta dur and Vitron), the germination rate of the stressed seeds is reduced compared to the control and this for both concentrations used (6 and 9 $\mathrm{g} / \mathrm{l})$. We can see that there is a decrease in the rate of germination corresponding to the increase in stress.

Figure 16 shows that the number of roots of stressed seeds of Gta dur variety is reduced when the applied stress increases $(6$ and $9 \mathrm{~g} / 1)$.

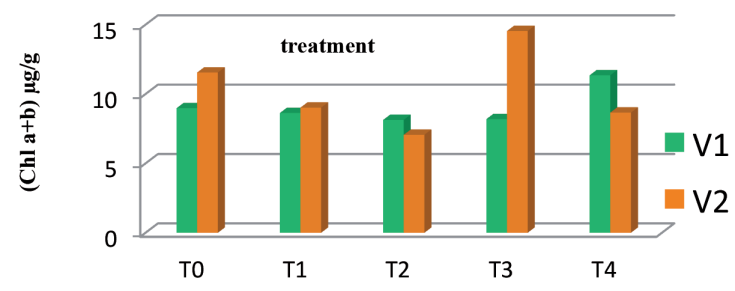

Figure 8. Variation in the Chlorophyll content $\mathrm{a}+\mathrm{b}(\mathrm{Chl} \mathrm{a}+\mathbf{b})$ of the two varieties of durum wheat exposed to different concentrations of $\mathrm{NaCl}$.

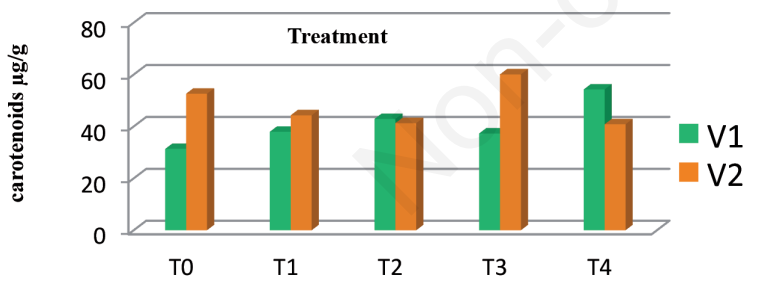

Figure 9. Variation of the carotenoids content of the two varieties of durum wheat exposed to different concentrations of $\mathrm{NaCl}$.

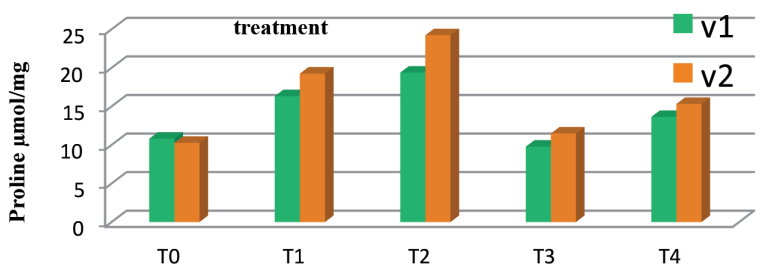

Figure 10. Variation of proline content of the two varieties of durum wheat exposed to the different concentrations of $\mathrm{NaCl}$.

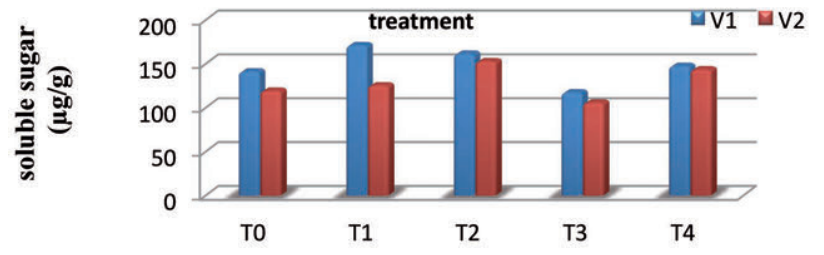

Figure 11. Variation of soluble sugar content of the two varieties of durum wheat exposed to different concentrations of $\mathrm{NaCl}$.

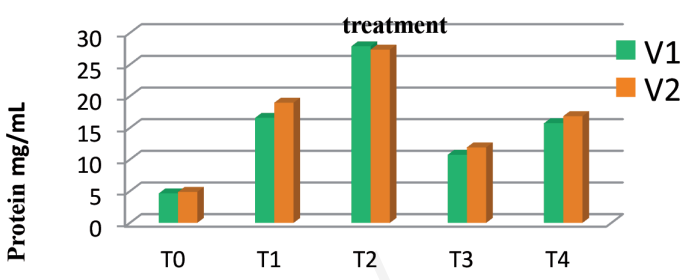

Figure 12. Variation in the protein content of the two varieties of durum wheat exposed to different concentrations of $\mathrm{NaCl}$.

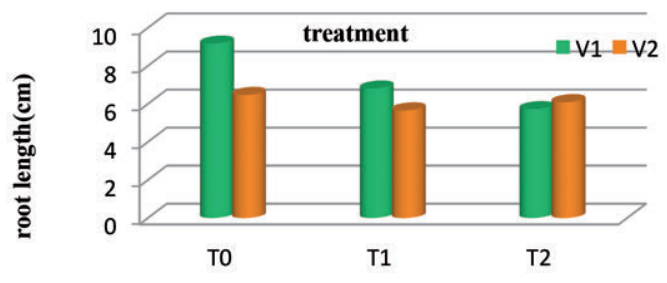

Figure 14. Variation of root length, in both durum wheat varieties, as a function of salt stress intensity.

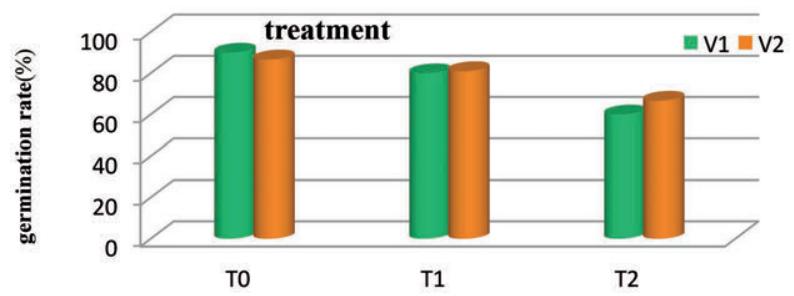

Figure 15. Variation in germination rate of the seeds of the two varieties of durum germinated on unsalted control medium, and on saline medium $(6$ and $9 \mathrm{~g} / 1$ of $\mathrm{NaCl})$. 


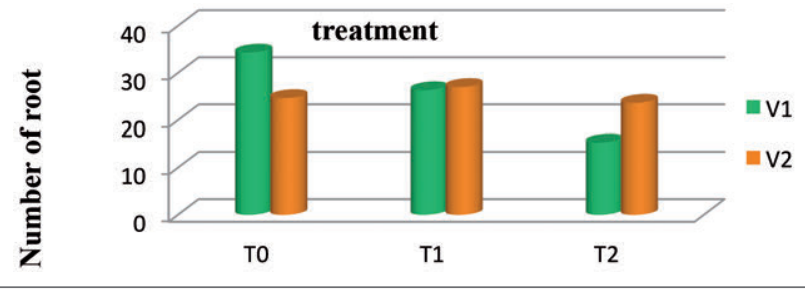

Figure 16. Variation in root number, in both durum wheat varieties, as a function of salt stress intensity.

\section{Discussion}

The study of the effects of different sodium chloride concentrations on seed germination of two varieties showed that germination capacity is affected by the increase in salt concentration.

In terms of elongation of the root, the salt stress seriously affected both varieties of durum tested.

According to our data, there is a non-significant difference between the two varieties for the two growth parameters evaluated during germination.

Our results show that root growth in length appears to be indifferent to salt stress and does not show a significant difference in salinity level, although the roots are the first point of contact between the plant and the soil. The emergence of the roots during germination would be controlled by the osmolarity of the medium while the subsequent growth of the seedling would be limited by the mobilization and transport of the reserves towards the embryonic axis. ${ }^{26}$

The increase of the $\mathrm{NaCl}$ content in the watering solutions causes the reduction of the height of the seedling, the leaf area and the biomasses of the varieties studied. This effect, which is common in glycophytes, has previously been observed in other varieties.

The decrease in vegetative growth observed in wheat seedlings can be explained by the fact that $\mathrm{NaCl}$ acts by increasing the osmotic pressure of the medium, which prevents the absorption of water by the root system. These leads, therefore, to a reduction in growth which is the result, at the cellular level, of a decrease in the number of cell divisions. ${ }^{27}$ The immediate response to salt stress is the reduction in the rate of expansion of the leaf area which leads to the cessation of expansion if the concentration of salt increases. ${ }^{28}$ Our results clearly show that durum wheat growth is better in the absence of salt or in a medium enriched with low concentration of $\mathrm{NaCl}(6 \mathrm{~g} / 1)$. As the salt concentration increases, a decrease in sprouted seed levels occurs at the concentration of 6 and $9 g / 1$ $\mathrm{NaCl}$. This shows that germination of seeds in the presence of salt stress varies from one variety to another.

Salinity affects different physiological mechanisms, including changes in ionic balance, and enzymatic activity perturbations. Resistance and / or adaptation of plants to salinity would depend on their ability to sustain themselves in adverse conditions by avoiding or tolerating stress. This tolerance is dependent on the severity of stress, variety and duration of exposure.

The results for water contents are shown in Figure 4, representing the average values of the water content of the leaves stressed by the different treatments compared to the control. It is noted that the water content of the leaves is irregular and there are large fluctuations. For both varieties, it is noted that the water content of the control plants is less important compared to those stressed.

The reduction of aerial and root biomasses under the effect of high salt concentrations has been reported in both varieties by several authors. ${ }^{29}$ We can explain the reduction of stalks and leaves under saline conditions, the increase in temperature and the lack of water at the time of growth, which acts at the height of the stalks of wheat; or maybe the different populations tested have differences in the accumulation of mineral ions between different parts of the plant.

Concerning growth, the general effect of salinity is reflected in the reduction of biomass, and can be explained by ionic problems. ${ }^{30}$

Observation of the $\mathrm{Chl} \mathrm{a,} \mathrm{b}$ and carotenoids contents show that all varieties were negatively affected by salt stress. Indeed, the highest dose of $\mathrm{NaCl}$ (severe stress) reduced the $\mathrm{Chl}$ a content in both varieties studied.

Concerning $\mathrm{Chl} \mathrm{b}$ and carotenoids pigments, an identical effect was also noted, that is to say, a decrease in contents in both varieties treated. These results are in line with previously published data. ${ }^{31}$

On the other hand, the application of a moderate stress $(6 \mathrm{~g} / \mathrm{l})$ of $\mathrm{NaCl}$ induced a significant increase in the content of $\mathrm{Chl}$ a in Vitron and Gta dur varieties.

The plausible explanation for the reduction of pigments in photoreceptors, in particular $\mathrm{Chl} \mathrm{a,} \mathrm{b}$ and carotenoids, is given by Epron et al., ${ }^{32}$ since the sensitivity of plants to salt $(\mathrm{NaCl})$ during and after stress was less affected than we observed in Chl a. Salt stress or irrigation of plants with saline water causes an alteration of the photosynthetic process. To counteract the effect of salt, plants will readjust their osmotic potential by accumulating compatible organic solutes such as proline, soluble sugars and proteins. ${ }^{32}$ The results obtained in this work show that the elevation of protein content in the roots is associated with salinity. In fact, the doses applied during stress stimulated protein synthesis in wheat. Moreover, Tewari and Singh ${ }^{33}$ write that root protein content is decreased in response to salt stress. Examination of the biochemical response of the proline content in the leaves shows that the accumulation of this amino acid varies from one variety to another; these results are consistent with other research. ${ }^{31}$

Proline is a free amino acid considered as a biomarker of stress. Genes involved in the synthesis of osmoprotectants are over expressed under the influence of salt stress. ${ }^{33}$ In transgenic plants, it has been found that an accumulation of mannitol, glycine, betaine ${ }^{34}$ and proline improves their tolerance to salt stress. Indeed, the accumulation of proline in the root and foliar system of plants is among the most remarkable manifestations induced by salt and water stress. The presence of proline in the leaves is often correlated with the ability of plants to survive under stress. This amino acid certainly comes from an induced and salt-induced biosynthesis or a release of pre-synthesized proteins by the phenomenon of proteolysis. ${ }^{35}$

The dosage of soluble sugars extracted from the leaves of the studied varieties has shown that there is generally a positive correlation between the amount of accumulated sugars with the duration of water stress and salt concentration. Stressed plants reacted by increasing the quantities of soluble sugars in their cells. ${ }^{36}$ Under high external salt concentration, it penetrates into the root cells, causing a proportional increase in accumulation of soluble sugar in the leaves.

Soluble sugars are considered bioindicators of the degree of salinity tolerance in several species. ${ }^{37}$ Indeed, they play an essential role in the protection of membranes against dehydration. ${ }^{38}$ Many studies have found that salt stress causes an increase in soluble sugar content in most plants subjected to salt stress. Our results are in perfect agreement with these studies, which reflect the ability of the species to adapt to salt stress by using soluble sugars as a means of accommodating stress to readjust their osmotic potential. 
CAT plays an important role in the transformation and elimination of hydrogen peroxide $\left(\mathrm{H}_{2} \mathrm{O}_{2}\right)$ into $\left(\mathrm{H}_{2} \mathrm{O}\right)$. According to our results, the activity of this enzyme was affected by salinity. Similar studies have shown that the treatment of plants with saline solutions causes a reduction in the activity of this enzyme in wheat, especially with the $6 \mathrm{~g} / \mathrm{l}$ dose of $\mathrm{NaCl}$. On the other hand, the $9 \mathrm{~g} / \mathrm{l}$ dose stimulated CAT activity. ${ }^{39}$ In general, CAT is stimulated at low doses and inhibited at high doses. This change in enzyme activity is dependent on the severity of salt stress, variety, and stage of development. ${ }^{39}$

\section{Conclusions}

Land salinization is a major problem on a global scale. According to FAO, it is already affecting at least 400 million ha and is seriously threatening an equivalent area (FAO and ITPS, 2015). ${ }^{40}$

Salinity affects plant growth through many mechanisms of cellular metabolism, such as: nutrient uptake, photosynthesis alteration, respiration, protein and nucleic acid synthesis, accumulation of organic solutes, enzyme activity, hormonal balance and water availability.

As a result of salt stress the plants produce reactive oxygen species called ROS. Indeed, the cellular structures are threatened following the production of these ROS. However, plants have an enzymatic and non-enzymatic antioxidant system to neutralize these free radicals that are toxic to cell metabolism. But beyond a certain limit and in extreme cases, salt accelerates the production of ROS, which then exceeds the capacity of the antioxidant system of cellular metabolism. In higher plants, the major antioxidant enzymes for detoxification are: Catalase (CAT), Superoxide Dismutase (SOD), Ascorbate Peroxidase (APX), etc.

The work done in this study has allowed us to have some information on the different effects of salt stress on physiological, morphological and biochemical parameters.

In the germination test, it has been shown that sodium chloride affected the germination of wheat seeds. The dose-effect is important: the higher the saline concentration, the lower the germinal parameters. It should be noted that the highest concentration caused an inhibition of this process in both varieties.

In the growth test, wheat varieties expressed altered morphological-physiological parameters as a decrease in leaf area, relative water content, water loss rate. The biochemical reactions of wheat against this salt stress show that certain variables such as soluble sugars, total proteins and the amino acid proline have been modified and disturbed. These disturbances are usually direct responses to salt stress caused to plants. The modification of these components makes possible to understand the adaptation and the behavior of the plant in saline conditions and to define the physiological and biochemical criteria of salt tolerance.

The results indicate that the levels of proline, soluble sugars and total protein in the roots of the salt-stressed seedlings are higher compared to controls in both Gta dur and Vitron varieties. The accumulation of these compounds can indeed play a role in the osmo-regulation of cells in case of water deficit and allow water absorption under hyper-osmotic conditions.

During a saline or hydrous stress, the inhibition of photosynthesis, and more precisely the

electron leakage due to the decrease of $\mathrm{CO}_{2}$ fixation, leads to a high accumulation of ROS.

The detoxification of ROS is a key element of plant defense to biotic and abiotic stress. The agents responsible for this detoxification are antioxidant enzymes; Catalase (CAT) is among these enzymes that play an important role in the transformation and elimination of hydrogen peroxide $\left(\mathrm{H}_{2} \mathrm{O}_{2}\right)$ into $\left(\mathrm{H}_{2} \mathrm{O}\right)$. Our results reveal that the activity of this enzyme has been stimulated by salinity.

We can conclude that the effect of salt stress in both varieties translating in an irregular way on the studied morpho-physiological and biochemical parameters. Finally, this comparative study shows that under saline stress important differences in behavior appear, that can be explained taking into account different treatments and different varieties.

\section{References}

1. Karakaş A. Motivational attitudes of ELT students towards using computers for writing and communication. J TEwT 2011;11:37-53.

2. Nour A, Brinis L. [Effet du stockage sur la vigueur et la viabilité des semences de deux variétés de blé dur (Triticum durum Desf.).] Rev Sci Technol Synthèse 2016;32:22 -9. [Article in French].

3. Greenway H, Munns R. Mechanism of salt tolerance in nonhalophytes. Ann Rev Plant Physiol 1980;31:149-90.

4. Selmi R. [Fin du mythe de l'autosuffisance alimentaire et place aux avantages comparatifs.] Rev Afrique Agriculture 2000;280:30-2. [Article in French].

5. Baatour O, M'rah S, Ben Brahim N, et al. [Réponse physiologique de la gesse (Lathyrus sativus) à la salinité du milieu.] Rev Régions Arides 2004;1:346-58. [Article in French].

6. Hayek T, Abdelly C. [Effets de la salinité sur l'état hydrique foliaire, la conductance stomatique, la transpiration et le rendement en grains chez 3 populations de mil (Pennisetum glaucum (L.) R. Br.).] Rev Régions Arides 2004;1:273-84. [Article in French].

7. Zhang J, Nguyen HT, Blum A. Genetic analysis of osmotic adjustment in crop plants. J Exp Bot 1999;50:291-302.

8. Martinez JP, Silva H, Ledent JF, Pinto M. Effect of drought stress on the osmotic adjustment, cell wall elasticity and cell volume of six cultivars of common beans (Phaseolus vulgaris L.). Eur J Agron 2007;26: 30-8.

9. Moinuddin A, Fischer R, Sayre K, Reynolds MP. Osmotic adjustment + wheat in relation to grain yield under water deficit environments. Agro J 2005;97:1062-71.

10. Parida AK, Das AB. Salt tolerance and salinity effects on plants. Rev Ecotoxicol Environ Saf 2005;60:324-49.

11. Teakle N, Flowers T, Real D, Colmer T. Lotus tenuis tolerates the interactive effects of salinity and water logging by 'excluding' $\mathrm{Na}+$ and $\mathrm{Cl}-$ from the xylem. J Exp Biol 2007;58:2169-80.

12. Shen B, Jensen RG, Bohnert HJ. Increased tolerance to oxidative stress in transgenic plants by targeting mannitol biosynthesis to chloroplasts. Plant Physiol 1997;113:1177-83.

13. Tsugane K, Kobayashi K, Niwa $Y$, et al. A recessive Arabidopsis mutant that grows photo-autotrophic ally under salt stress shows enhanced active oxygen detoxification. Plant Cell 1999;11:1195-206.

14. Allen R.D. Dissection of oxidative stress tolerance using transgenic plants. Plant Physiol 1995;107:1049-54.

15. Munns R, James RA, Lauchli A. Approaches to increasing the salt tolerance of wheat and other cereals. J Exp Biol 2006; 27:1025-43.

16. Moorby J, Besford RT. Mineral nutrition and growth. In: 
Encyclopedia of Plant Physiology New Series Vol.15 B: Iorganic Plant Nutrition. (eds). A. Laüchli and R.L. Bieleski. Springer-Verlag: Berlin; 1983. pp 481-515.

17. Ottow E, Brinker M, Frit E, et al. Populus euphratica displays apoplastic sodium accumulation, osmotic adjustment by decreases in calcium and soluble carbohydrates, and develops leaf succulence under salt stress. Plant Physiol 2005;139: 1762-72.

18. Morant-Manceau A., Pradier E., Tremblin G. Osmotic adjustment, gas exchanges and chlorophyll fluorescence of a hexaploid triticale and its parental species under salt stress. J Plant Physiol 2004;161:25-33.

19. USSL Salinity Laboratory. Diagnosis and Improvement of Saline and Alkaline Soils. US Department of Agriculture Handbook 1954;60:160.

20. Soltner D. [Les bases de la production végétale - Le climat: climatologie-pédologie-conservation des sols, phytotechnie générale.] Collection Sciences et techniques agricoles. eds 9th. Librairie Eyrolles: Paris 5e; 2007 pp 328. [Article in French].

21. Maillard J. [Le point sur l'Irrigation et la salinité des sols en zone sahélienne. Risques et recommandations.] Handicap Int 2001:34. Available from: https://it.scribd.com/document/ 251588432/Le-Point-Sur-Lirrigation-Et-La-Salinite-Des-Solsen-Zone-Aride. [Article in French].

22. Barrs HD. Determinations of water deficits in plant tissues. In: Water Deficits and Plant Growth. ed. T.T. Kozlowski. Academic Press: New York; 1968;1:235-68.

23. McKinney-Arnon D. Copper enzymes in isolated chloroplasts. Polyphenoloxidase in Beta vulgaris. Plant Physiol 1949; 24:1-15.

24. Monneveux P, Nemmar M. [Contribution à l'étude de la résistance à la sécheresse chez le blé tendre (Triticum aestivum L.) et chez le blé dur (Triticum durum Desf.): Etude de l'accumulation de la proline au cours du cycle de développement.] Agronomie 1986;6:583-90. [Article in French].

25. Shields R, Burnett W. Determination of protein bound carbohydrate in serum by a just modified anthrone method. Anal Chem 1960;32:885-86.

26. Bradford MM. A rapid and sensitive method for the quantization of microgram quantities of protein utilizing the principle of protein-dye binding. Anal Biochem 1976;72:248-54.

27. Cakmak I, Horst WJ. Effect of aluminum on lipid-peroxidation, superoxide dismutase, catalase, and peroxidase activities in root tips of soybean (Glycine max). Physiol Plant 1991;83:463-68.

28. Doran JC, Gunn V. Treatments to promote seed germination in Australian acacias. In: Australian Acacias in Developing Countries. J.W. Turnbull 1986; ed, Gympie, Australia: 57-63.

29. Gomes-Filho E, Prisco JT, Campos FAP, Enéas-Filho J. Effects of $\mathrm{NaCl}$ salinity in vivo and in vitro on ribonuclease activity of Vigna unguiculata cotyledons during germination. Physiol Plant 1983;59:183-8.

30. Benamar B, Florence DM. [Effet du stress salin sur la germination et la croissance in vitro du pistachier (Pistacia vera L.).] C R Biologies 2009;332:752-8. [Article in French].

31. Wang Y, Nil N. Changes in chlorophyll, ribulose biphosphate carboxylase-oxygenase, glycine betaine content, photosynthesis and transpiration in Amaranthus tricolor leaves during salt stress. J Hortic Sci Biotechnol 2000;75:623-7.

32. Epron D, Farque L, Lucot E, Badot PM. Soil CO2 efflux in a beech forest: dependence on soil temperature and soil water content. Ann For Sci 1999;56: 221-6.

33. Tewari TN, Singh, BB. Stress studies in lentil (Lens esculenta M.) II. Sodicity induced changes in chlorophyll, nitrate and nitrate reductase, nucleic acid, proline, yield and yield components in lentil. Plant Soil 1991;136: 225-30.

34. Handa SS, Sharma A, Chakarborti KK. Natural products and plants as a liver protecting drug. Fitoterapia 1986;57:307-51.

35. Parida AK, Das AB. Salt tolerance and salinity effects on plants. Rev Ecotoxicol Environ Saf 2005;60:324-49.

36. Loreto N, Ruben L, Javier R, et al. The response of carbon metabolism and antioxidant defenses of alfalfa nodules to drought stress and to the subsequent recovery of plants. Plant Physiol 2007; 144:1104-14.

37. Zhu H, Pan S, Gu S. Amino acid residue specific stable isotope labeling for quantitative proteomics. Rapid Commun Mass Spectrom 2002;16:2115-23.

38. Prasad PVV, Craufurd PQ, Summerfield RJ, Wheeler TR. Effects of short episodes of heat stress on floral production and fruit-set of groundnut (Arachis hypogaea L.). J Exp Bot 2000;51:777-84.

39. Delauney AJ, Verma DPS. Proline biosynthesis and osmoregulation in plant. Plant J 1993;4:215-23.

40. FAO and ITPS. State of the World's Soil Resources: Technical Summary: Intergovernmental Technical Panel on Soils, 2015. 